\title{
The pro-cyclical impact of Basel III regulatory capital on bank capital risk ${ }^{1}$
}

\author{
Guoxiang Song
}

\section{Introduction}

During the recent financial crisis, the market focused on tangible common equity rather than regulatory capital as the measure of a bank's capital adequacy (Tarullo, 2011). Therefore, to raise the quality of regulatory capital, Basel III capital rules recognize unrealized gains and losses on all available - for - sale (AFS) securities measured at fair value in its Common Equity Tier 1 Capital (CET1). However, as it is argued that fair value accounting may have reinforced the pro-cyclicality of regulatory capital standards for banks (ECB, 2004; IMF, 2008; BCBS, 2011; Song, 2012), Basel III regulatory capital may further enhance the pro-cyclicality of regulatory capital ratios. Consequently, Basel III regulatory capital standards may have significant implications for bank supervision and bank capital risk management. To address this issue, this paper investigates the procyclical impact of Basel III regulatory capital on regulatory capital ratios of six U.S. global systemically important banks (G-SIBs) since 2007. And the results indicate that Basel III regulatory capital will enhance the pro-cyclicality of bank capital risk.

Before Basel III, major components of regulatory Tier 1 capital measured using fair value accounting are trading revenues and realized gains or loess on AFS securities. One factor for excluding unrealized gains or losses on AFS securities from Tier 1 capital is the volatility created by fair value accounting especially that generated by changes in interest rates, as it is not indicative of a bank's true financial condition (Greenspan, 1990). Another factor is that unrealized gains or losses on AFS securities are not as informative and value relevant as net income to securities price (Ball et al., 2012; Dong et al., 2013).

\footnotetext{
${ }^{1}$ I acknowledge the helpful comments of Professor Geoff Meeks, Professor Niklas Wagner and Professor Jonathan Batten.
} 
However, Basel III regulatory capital includes unrealized gains or losses on AFS securities as it is argued that unrealized losses could have an actual impact on a bank's capital in some specific time period (The Agencies, 2013). But this may add to the pro-cyclicality and volatility to bank capital requirements (ISDA, 2012).

In order to examine what difference Basel III regulatory capital definition will make to bank supervision and bank capital risk management, this paper will compare the impacts of three main components of accounting gains and losses on the Basel III leverage ratio and the Tier 1 capital ratio. The first component is the recurring fair value gains and losses on trading assets, which are currently parts of Tier 1 capital. The second component is the recurring unrealized fair value gains and losses on AFS securities. They are included in Basel III Tier 1 capital but not the Tier 1 capital definition before Basel III. To provide evidence on the relative pro-cyclical and volatile nature of the impact of these accounting gains and losses, realized gains and losses on AFS securities are also examined.

The third component is the provisions for loan-loss reserves which are the impairments recognized for held-for-investment loans (HFI). The increase in these provisions is currently deducted from net income and Tier 1 capital. The behaviour of this component is compared with that of fair value accounting so that the relative pro-cyclicality of different accounting rules can be examined as loan loss provision under the current incurred loss approach is argued to be pro-cyclical (BCBS, 2011).

Some studies have found that these accounting gains or losses have an obvious impact on bank regulatory capital measures used before Basel III during this financial crisis. For example, SEC (2008) examines 22 U.S. bank failures which were mainly small banks during 2008, and finds that credit losses had played a meaningful role. However, Shaffer (2010) finds that realized and unrealized gains or losses resulting from fair value accounting reduced Tier 1 capital by more than $8 \%$ for some large US banks, and unrealized losses on AFS securities reduced tangible common equity ratios by more than 50\% for some large US banks. Badertscher et al. (2012) also investigate the impact of unrealized gains and losses on AFS securities. However, they found that fair value changes excluding trading 
assets have a smaller effect on Tier 1 capital ratio than the provision for loan losses for 150 U.S. Bank Holding Companies (BHCs) in the crisis. Laux and Leuz (2010) recognize the impact of huge losses on trading assets for a few very large BHCs, and Ball et al. (2012) suggest trading losses could have a negative impact on investor sentiment for banks' shares during the crisis because they may increase information asymmetry.

However, there is little empirical evidence on the pro-cyclical impact of Basel III regulatory capital on bank regulatory capital ratios. Many papers investigate the pro-cyclicality of bank capital regulation based on simulation exercises (IMF, 2008; ECB, 2009). And they use large samples which mix large and small banks, so there is no clear evidence for G-SIBs.

This paper designs models to measure the direct impact of accounting rules on a bank's Basel III regulatory capital ratios, and attempts to explore what would happen to U.S. G-SIBs if Basel III regulatory capital definition is applied. Six U.S. G-SIBs, i.e. Citigroup (C), JPMorgan Chase (JPM), Bank of America (BAC), Wells Fargo \& Company (WFC), The Bank of New York Mellon (BK) and State Street Corporation (STT) are used as cases to investigate the empirical evidence during the period 2007 to 2013. Among them, C, JPM, BAC and WFC are the four largest U.S. commercial BHCs. BK and STT are two important clearing and settlement banks. In addition, they are global systemically important financial institutions (G-SIFIs) identified by the FSB and BCBS based on the BCBS methodology using data as of end-2009 (FSB, 2011)2.

Why is it necessary to investigate these U.S. G-SIBs? First, the effect of fair value accounting is argued to be more pronounced at large banks than at small banks (Shaffer, 2010). In the sample, the smallest proportion of assets measured at fair value is $24 \%$ in the second quarter of 2007(see Table 1). Second, these banks are G-SIFIs whose failure may have a devastating impact on the financial system (FSB, 2011), and that is why special regulations will be applied to them after the crisis (Tarullo,

\footnotetext{
${ }^{2}$ Goldman Sachs and Morgan Stanley are the remaining two U.S. G-SIFIs. They are not included in the sample because they were approved as BHCs at the end of 2008.
} 
2011). Third, the general results from large sample studies which mix large and small banks cannot describe what happens to large banks but may reflect the findings for small banks as there is a big difference in using accounting rules between large banks and small banks. Finally, there are also significant differences among G-SIBs as can be seen from Table 1. For example, STT measured 60\% of total assets at fair value whereas WFC measured $24 \%$ of total assets at fair value right before this crisis.

\section{Insert Table 1 here.}

This paper investigates the pro-cyclical impact of Basel capital standards by directly examining the correlations between U.S. GDP growth rate and the impact of different accounting gains and losses on regulatory capital ratios estimated using the models in this paper. It finds that the Basel III leverage ratio and the Tier 1 capital ratio do show stronger correlations with U.S. GDP growth rate than these ratios under capital standards before Basel III, which suggests that including unrealized gains and losses on AFS securities may increase the pro-cyclicality of regulatory capital ratios. The results also indicate that both fair value and loan loss provisions have a significant pro-cyclical impact on Basel III regulatory capital ratios, and these two impacts may reinforce each other. As an expected loss (EL) approach for loan loss provisioning will use forward-looking information as fair value does, its adoption may increase the positive correlation between the impact of fair value and that of loan loss provision. Moreover, this paper finds these two impacts also are negatively sensitive to long-term interest rate changes, and Basel III capital ratios have a strong negative sensitivity to both short-term and long-term interest rates.

These results have significant implications for bank capital risk management. For G-SIBs which hold a significant share of AFS securities such as STT and BK, the Basel III countercyclical buffer of 2.5\% plus the additional loss absorbency requirements of $2.5 \%$ for G-SIBs (BCBS, 2013a) may not be enough to mitigate the capital risk generated by an economic recession or the normalization of interest rates from the current low level. This risk is becoming realistic as U.S. monetary policy has started to 
taper quantitative easing. In addition, the Basel III Liquidity Framework requires banks to hold more high quality liquid assets (HQLA) to meet Liquidity Coverage Ratio (LCR) requirement (BCBS, 2013b). This means that banks will have to hold more AFS securities after 2015 and as a result, longterm interest rate changes may have a much greater impact.

This paper contributes to the literature and current debate on bank capital regulation in several aspects: First, the pro-cyclical impact of fair value accounting on Basel III regulatory capital ratios is significant as including unrealized gains and losses on AFS securities increases the portion of Tier 1 capital measured at fair value. Even though proposed new accounting standards for financial instruments by IASB and FASB eliminate the AFS category, still, a category of fair value through other comprehensive income (FVOCI) will include AFS securities, so their impact on regulatory capital will not disappear (IASB, 2013a). Therefore, it will be necessary for banks to disclose unrealized gains and losses arising from fair value accounting under new accounting standards so that their impact on regulatory capital can be evaluated separately from realized gains and losses. Second, the increase in the pro-cyclical impact of fair value coupled with the impact of the proposed forward looking provisioning (BCBS, 2011) suggests that Basel III regulatory capital ratios may be more procyclical. This may not bring bank capital risk management based on regulatory capital measures into line with the actual risk of banks. Third, the strong negative sensitivity of Basel III capital ratios to interest rates may increase bank capital risk significantly when interest rates normalize.

The remainder of the paper proceeds as follows. Section 2 introduces the model for estimating the effect of accounting rules on Basel III regulatory capital ratios. Section 3 examines the empirical evidence for the pro-cyclicality of Basel III regulatory capital ratios and the pro-cyclical impact of accounting rules. Section 4 discusses the implications for bank capital risk. Section 5 concludes.

\section{The model}

One of the main differences between Basel III and capital standards before Basel III such as Basel II and Basel I is that unrealized gains or losses on AFS securities are recognized in Basel III Tier 1 
capital. Therefore, the impact of accounting gains and losses on Basel III leverage ratio and Tier 1 capital ratio will be different from that on the leverage ratio and Tier 1 capital ratio before Basel III. Here simplified models based on the formulae of the leverage ratio and the Tier 1 capital ratio are developed to estimate the impact of different accounting gains and losses, and show the different impacts they have on Basel III capital standards and capital standards before Basel III.

\subsection{The effect of the accounting gains or losses on the leverage ratio}

The effect of an accounting gain, which is recognized in Tier 1 capital, on leverage ratio can be used as an example to illustrate the basic model.

Assume that a bank has a leverage ratio of $\mathrm{L} \%(0<\mathrm{L}<100)$, and original Tier 1 capital is $\mathrm{x}$, and total assets which are used for the leverage ratio calculation are $y$, then $L \%=\frac{x}{y}$. Assume that an accounting gain increases the bank's Tier 1 capital $\mathrm{x}$ by $\mathrm{k} \%(0<\mathrm{k})$, thereby increasing total assets by the amount of $\mathrm{x} * \mathrm{k} \%$, then the new leverage ratio will be $L_{1} \%=\frac{(1+\mathrm{k} \%) * \mathrm{x}}{\mathrm{y}+\mathrm{k} \% * \mathrm{x}}$. So the effect of this gain on leverage ratio can be calculated using $\mathrm{DL}=\mathrm{L}_{1} \%-\mathrm{L} \%$.

$\mathrm{DL}=\frac{(1+\mathrm{k} \%) * \mathrm{x}}{\mathrm{y}+\mathrm{k} \% * \mathrm{x}}-\mathrm{L} \%$

$=\frac{(1+\mathrm{k} \%)}{1 / \mathrm{L} \%+\mathrm{k} \%}-\mathrm{L} \%$

$=\frac{\mathrm{L} \% * \mathrm{k} \% *(1-\mathrm{L} \%)}{1+\mathrm{k} \% * \mathrm{~L} \%}$

So $\mathrm{DL}>0$ because $(1+\mathrm{k} \% * \mathrm{~L} \%)>0, \mathrm{k}>0,1-\mathrm{L} \%>0$.

Therefore, it can be seen that if this accounting gain increases Tier 1 capital by $\mathrm{k} \%$, leverage ratio increases by $\frac{\mathrm{L} \% * \mathrm{k} \% *(1-\mathrm{L} \%)}{1+\mathrm{k} \% * \mathrm{~L} \%}$.

The same analysis can be applied to the case where an accounting loss decreases the bank's Tier 1 capital $\mathrm{x}$ by $\mathrm{k} \%(0<\mathrm{k}<100)$, thereby decreasing total assets by the amount of $\mathrm{x} * \mathrm{k} \%$. The new leverage 
ratio will be $\frac{(1-\mathrm{k} \%) * \mathrm{x}}{\mathrm{y}-\mathrm{k} \% * \mathrm{x}}$. So $\mathrm{DL}=\frac{-\mathrm{L} \% * \mathrm{k} \% *(1-\mathrm{L} \%)}{1-\mathrm{k} \% * \mathrm{~L} \%}<0$. This accounting loss will lower the leverage ratio.

The impact of unrealized gains or losses on AFS securities on the Basel III leverage ratio can be estimated using this model. However, the impact of these gains or losses on the leverage ratio computed using the Tier 1 capital definition before Basel III should be estimated differently as such gains or losses only affect the denominator of the leverage ratio. This impact can be estimated simply by changing the denominator of the leverage ratio by the magnitude of such gains or losses. If the magnitude is $\mathrm{k} \%(-100=<\mathrm{k})$ of Tier 1 capital $\mathrm{x}$, then $\mathrm{DL}=-\frac{(L \%)^{2} * \mathrm{k} \%}{1+\mathrm{k} \% * \mathrm{~L} \%}$.

\subsection{The effect of the accounting gains or losses on the Tier 1 capital ratio}

It is difficult to evaluate the effect of the accounting gains or losses on risk-weighted capital ratios as there are different approaches to measuring risk-weighted assets. Here the idea of an internal ratingsbased approach (IRB) under Basel II to calculating the change of risk-weighted assets due to the unexpected change of an individual exposure is applied to estimate the change of risk-weighted assets (Saunders and Cornett, 2011): First, calculate the capital requirement for an individual exposure. Second, use this capital requirement times $\frac{1}{8 \%}$ to obtain risk-weighted assets which this new regulatory capital can support. Here $\frac{1}{8 \%}$ is the asset multiplier for an $8 \%$ capital ratio under the Basel Accord. Then the difference between the estimated new risk-weighted capital ratio and the original one is used as an estimate for the change of actual risk-based capital ratio because of this exposure.

With this approach, an accounting gain or loss is treated as one new individual exposure ${ }^{3}$. This is reasonable because this paper attempts to investigate the impact of the unrealized gains or losses on

\footnotetext{
${ }^{3}$ But for simplicity, Badertscher et al. (2012) estimate the impact of the unrealized losses on Tier 1 capital ratios by assuming that such losses are realized, i.e. starting from Tier 1 capital ratios at the end of the reporting period, they add back the effect of such losses on risk-weighted assets to the denominator to estimate the Tier 1 capital ratios which are purged of such unrealized losses. With the model in this paper, however, the change in risk-weighted assets is estimated as if there is a new exposure when an unrealized gain or loss occurs. The "as
} 
bank capital regulation. To simplify, assume that a bank has an original Tier 1 capital ratio of $\mathrm{R} \%(0$ $=<R=<100$ ), and an original Tier 1 capital of $x$. Then total risk-weighted assets (RWA) which are used for the Tier 1 capital ratio calculation for the base period according to the Basel Accord can be calculated as RWA $=\frac{\mathrm{x}}{\mathrm{R} \%}$. Assume that an accounting gain or loss is $\mathrm{k} \%(-100=<\mathrm{k})$ of this bank's Tier 1 capital $\mathrm{x}$, and it changes RWA by the amount of $\frac{\mathrm{M} * \mathrm{x} * \mathrm{k} \%}{8 \%}(0=<\mathrm{M}=<8 \%)$. Here $\mathrm{M}$ is the regulatory capital requirement for the new exposure due to this accounting gain or loss. Before Basel III, for trading book items, the maximum $\mathrm{M}$ is $1.1 \%$ (FSA, 2009), which is used in this paper; however, for banking book items, the maximum M is $8 \%$ (FSA, 2009). Then the effect of an accounting gain or loss on Tier 1 capital ratio can be estimated using the difference between the new Tier 1 capital ratio and the original ratio R\%. Here this difference is denoted as DR.

When this accounting gain or loss is recognized in Tier 1 capital, the new Tier 1 capital ratio is $\frac{(1+\mathrm{k} \%) * \mathrm{X}}{\mathrm{RWA}+\frac{\mathrm{k} \% * \mathrm{X} * \mathrm{M}}{8 \%}}=\frac{(1+\mathrm{k} \%) * \mathrm{X}}{\frac{\mathrm{x}}{\mathrm{R} \%}+\frac{\mathrm{k} \% * \mathrm{X} * \mathrm{M}}{8 \%}}$ $=\frac{\mathrm{R} \% *(1+\mathrm{k} \%)}{1+\frac{\mathrm{k} \% * \mathrm{M} * \mathrm{R} \%}{8 \%}}$ As a result, $\mathrm{DR}=\frac{\mathrm{R} \% *(1+\mathrm{k} \%)}{1+\frac{\mathrm{k} \% * \mathrm{M} * \mathrm{R} \%}{8 \%}}-\mathrm{R} \%$ $=\frac{\mathrm{R} \% * \mathrm{k} \% *\left(1-\frac{\mathrm{M} * \mathrm{R} \%}{8 \%}\right)}{1+\frac{\mathrm{k} \% * \mathrm{M} * \mathrm{R} \%}{8 \%}}$

Whether DR is positive depends on whether $\mathrm{k}$ is positive because $-100=<\mathrm{k}, 0=<\mathrm{R}=<100$ and $0=<$ $\mathrm{M}=<8 \%$. This indicates that an accounting gain will increase Tier 1 capital ratio whereas an

if' Tier 1 capital ratios is computed by starting from Tier 1 capital ratios at the beginning of the reporting period. Such results can show a more accurate impact. This is because Tier 1 capital ratios at the end of the reporting period are normally contaminated by many other factors such as capital raising during the reporting period, which may make the impact of the accounting gains or losses appear to be much less important. 
accounting loss will decrease the Tier 1 capital ratio. But the magnitude of the change depends on the capital requirement $(\mathrm{M})$ for the new exposure.

The model here can used to estimate the impact of accounting gains or losses on trading assets, unrealized and/or realized gains or losses on AFS securities on Basel III Tier 1 capital ratio. However, the impact of the loan loss provision can be estimated simply by changing the numerator of the Tier 1 capital ratio by the magnitude of $\mathrm{k} \% * \mathrm{x}$ if the provision is $\mathrm{k} \%$ of Tier 1 capital $\mathrm{x}$, and then $D R=$ $k \% * R \%$. This is because the provision for loan losses will affect Tier 1 capital but not RWA as the carrying value of loan and leases, which does not deduct the allowance for loan and lease, is used for computing RWA.

The impact of unrealized gains or losses on AFS securities on the Tier 1 capital ratio before Basel III should also be estimated differently as they only affect the denominator of the capital ratio. Their impact can be estimated simply by changing the denominator of Tier 1 capital ratio by the magnitude of $\frac{\mathrm{M} * \mathrm{X} * \mathrm{k} \%}{8 \%}$ if such gain or loss is $\mathrm{k} \%$ of Tier 1 capital $\mathrm{x}$. Then $D R=-\frac{(R \%)^{2} * \mathrm{k} \% * \mathrm{M}}{8 \%+\mathrm{k} \% * \mathrm{M} * \mathrm{R} \%}$.

\section{The pro-cyclicality and interest rate sensitivity of Basel III regulatory capital ratios}

\subsection{The pro-cyclicality of the leverage ratio and the Tier 1 capital ratio}

The pro-cyclical impact of Basel III regulatory capital on bank capital ratios can be seen clearly from the correlations of regulatory capital ratios with real GDP growth rates. The business cycles are defined by real GDP growth rate: in economic expansions, GDP will grow; however, in economic contractions, GDP will decline. The pro-cyclicality of bank capital ratios should present itself as a positive correlation between capital ratios and GDP growth rates. Indeed, the results of Table 2 do show such pro-cyclicality.

(Insert Table 2 here) 
The pro-cyclicality of Basel III leverage ratio can be seen in Panel A of Table 2. This Panel reports the correlations between leverage ratios in quarter $t$ and GDP growth rates for quarter $t-1$, quarter $t$ and quarter $t+1$. In terms of Base III leverage ratio, there are both positive and negative correlations with GDP growth rate in quarter t-1. However, all correlations of six banks are positive with GDP growth rate in quarter $\mathrm{t}+1$ and their figures are around $20 \%$ or more. This clearly implies that high Basel III leverage ratio will be associated with high GDP growth rate in next quarter. Moreover, only one correlation with the GDP growth rate in quarter $t$ is negative but very small (i.e. -0.06 for JPM), indicating that overall, there is a pro-cyclicality in Basel III leverage ratio. However, in terms of the leverage ratio before Basel III, there is no clear pro-cyclicality as there are both positive and negative correlations with GDP growth rates in all quarters. It may be inferred, therefore, that Basel III regulatory capital generates the pro-cyclicality for leverage ratio.

The Basel III Tier 1 capital ratio also shows strong pro-cyclicality. All the sample, of banks in quarter $\mathrm{t}$ have positive correlations with GDP growth rates for quarter $\mathrm{t}-1$, quarter $\mathrm{t}$ and quarter $\mathrm{t}+1$ (see Panel $\mathrm{B}$ of Table 2). Moreover, the correlation coefficients are around 0.30 or more for quarter $t$ and quarter $\mathrm{t}+1$. This demonstrates that the pro-cyclicality of the Basel III Tier 1 capital ratio is much stronger than that of Basel III leverage ratios. This is easy to explain: as a higher GDP growth rate may reduce the risk of bank assets, the risk-weighted assets of banks may grow less than total assets, therefore, the Tier 1 capital ratio may increase more than the leverage ratio. In fact, it is found that banks could report strong risk-based capital ratios while they were building up excessive leverage during this crisis (BCBS, 2011).

However, the results for Tier 1 capital ratio before Basel III are relatively weaker than those for Basel III as there are two negative correlations for quarter $t-1$ and one for quarter $t$. But the pro-cyclicality of the Tier 1 capital ratio is still stronger than that of the leverage ratios before Basel III in terms of GDP growth rate in quarter $t+1$. One possible reason for this could be that when Tier 1 capital ratio is higher, banks may be in a better position to extend loans. 
The strong pro-cyclicality of the Basel III leverage ratio and the Tier 1 capital ratio can also be demonstrated by the correlations between those ratios for the six banks. This is because if there is such pro-cyclicality, then there should be positive and high correlations between these ratios for different banks. Indeed, Panel C of Table 2 reports that all correlations for Basel III leverage ratio are positive. For Basel III Tier 1 capital ratio, the correlations are stronger. To save space, the results are not reported here.

\subsection{Sources of the pro-cyclicality}

One source of the pro-cyclicality of Basel III capital ratios is the pro-cyclicality of the impact of accounting rules. Table 3 shows the pro-cyclical impact of both fair value accounting and loan loss provisions on Basel III leverage ratios.

\section{(Insert Table 3 here)}

The strong pro-cyclicality of the impact of fair value accounting can be seen in Panel A of Table 3 . Even though some of the correlations of the impact of fair value in quarter $t$ with GDP growth rate in quarter t- 1 are relatively small and one of them is negative, its correlations with GDP growth rate in quarter $\mathrm{t}$ and quarter $\mathrm{t}+1$ for all six banks are positive, and most of these figures are around $40 \%$ or more. The positive correlations between these impacts of all banks (see Panel B of Table 3) also corroborate the strong pro-cyclicality of fair value accounting. Moreover, the strong pro-cyclical impact on the Basel III leverage ratio of unrealized gains and losses on AFS securities for each bank reported in Panel D of Table 3 may have contributed to such pro-cyclicality of fair value accounting.

The loan loss provision seems to have a much stronger pro-cyclical impact on Basel III leverage ratio. Panel A of Table 3 shows that all six banks in quarter t have positive correlations with GDP growth rates for all three quarters. Moreover, all figures for quarter t- 1 are around $45 \%$ or more. This indicates that past economic growth has a strong positive impact on loan loss provision, confirming that the incurred loss model may delay recognition of credit losses because credit losses are associated with past economic performance (IASB, 2013b). In addition, these impacts have a strong positive 
correlation with each other (to save space, the results are not reported here), also indicating the strong pro-cyclicality of historical cost accounting (FSA, 2009).

The pro-cyclicality of fair value accounting and historical cost accounting may have reinforced each other through their positive correlations. Panel $\mathrm{C}$ of Table 3 provides clear evidence in terms of their impact on the Basel III leverage ratio. Five banks have reported strong and positive correlations between the impacts of fair value and loan loss provision in quarter t. And all the sample of banks report strong and positive correlations between the impact of fair value in quarter $t$ and that of loan loss provision in quarter $\mathrm{t}+1$. The results for Basel III Tier 1 capital ratio are similar (to save space, they are not reported here).

These patterns of correlations also confirm that fair value is informative to investors (SEC, 2008) and regulators as it seems to have a clear correlation with the performance of the economy and loan loss provision. In addition, the introduction of an EL model for forward looking provisioning, which will recognize changes in expectations of credit losses, may probably enhance the correlation between the impact of fair value and that of loan loss provision on capital regulation. This is because the EL model will use forward-looking information and market information as fair value does (Song, 2012; IASB, 2013a, 2013b). As a result, the pro-cyclicality of Basel III regulatory capital may increase rather than decrease.

\subsection{Interest rate sensitivity}

As interest rates are found to be pro-cyclical (Sill, 1996), they also may generate some pro-cyclical impact on regulatory capital ratio. In addition, as prices of AFS debt securities are adversely affected by interest rates, Basel III capital ratios may be more sensitive to interest rates than regulatory capital ratios before Basel III.

\section{(Insert Table 4 here)}

Indeed, Basel III regulatory capital increases the negative sensitivity of regulatory capital ratios to interest rates as can be seen in Table 4. BK's leverage ratio before Basel III has a strong positive 
correlation with the yield of both 3- month U.S. Treasury Bills and 10-year U.S. Treasury Bonds (see Panel A of Table 4). However, its Basel III leverage ratio has a negative correlation with the shortterm interest rate, and a very small positive correlation with the long-term interest rate. In addition, for all other five G-SIBs, Basel III leverage ratios have a strong and similarly negative correlation with both short-term and long-term interest rates.

Moreover, both the Basel III Tier 1 capital ratio and the Tier 1 capital ratio before Basel III of all banks have shown significant and similar negative correlations with the yield of both 3- month U.S. Treasury Bills and 10-year U.S. Treasury Bonds (see Panel B of Table 4). Such negative sensitivity of the leverage ratio and the Tier 1 capital ratio may to some extent come from the negative sensitivity of the impact of fair value, unrealized gains or losses on AFS securities and loan loss provision on the regulatory capital ratios to long-term interest rates, as shown in Panel C and D of Table $4^{4}$.

\section{Implications for bank capital risk management}

\subsection{Pro-cyclicality of Basel III regulatory capital ratios and bank capital risk}

The pro-cyclical impact of Basel III regulatory capital on regulatory capital ratios has more significant implications for bank capital risk management than those of other Basel capital standards. This is because Basel III includes unrealized gains or losses on AFS securities in its regulatory capital. For banks which have a significant share of assets in AFS securities, the additional capital risk generated may be hard to manage.

(Insert Table 5 here)

\footnotetext{
${ }^{4}$ The results for Basel III Tier 1 capital ratio are very close to these reported here for Basel III leverage ratios. To save space, they are not reported.
} 
Indeed, this can be seen from the impact of unrealized gains and losses on AFS securities during the recent recession period and expansion period ${ }^{5}$. For example, STT and BK suffered significant unrealized losses on AFS securities during the recession period as they hold over $20 \%$ of assets in AFS securities (see Panel A and B of Table 5). Even though capital raising activities and other gains of STT and BK during the recession period may make the impact of these losses relatively smaller, their Basel III leverage ratio could still be decreased by 5.78 and 4.22 percentage points, and Basel III Tier 1 capital ratio could be reduced by 13.7 and 7.26 percentage points. At the beginning of the $4^{\text {th }}$ quarter 2007, the Basel III leverage ratio and the Tier 1 capital ratio estimated for STT are 5.3 and 11.4 percentage points, and those for BK are 6.7 and 9 percentage points. If the negative impact of unrealized gains and losses on AFS were included, at the end of the recession period, Basel III leverage ratio and Tier 1 capital ratio for STT would be -0.48 and -2.3 percentage points, and those for BK would be 2.48 and 1.74 percentage points. This clearly indicates that these banks would be critically undercapitalized. For other banks, the impact of unrealized gains or losses on AFS securities also depends on these banks' assets structure.

However, such pro-cyclical impact may overstate the actual capital risk. First, the impact of realized gains or losses on AFS securities on Basel III Tier 1 capital is much smaller for most banks. In fact, realized gains and losses on AFS securities for several banks have some positive impact over the recession period (see Panel A and B of Table 5). Therefore, Basel III may introduce substantial volatility to Tier 1 capital and regulatory capital ratios which does not reflect the actual risk.

Second, during the recent expansion period, the impact of unrealized gains or losses on AFS securities turned to be positive and again was much greater than that of realized gains or losses on AFS securities for most banks. This confirms that the impact of unrealized gains or losses on AFS is volatile and the probability of it being realized is small.

\footnotetext{
${ }^{5}$ According to the U.S. Business Cycle Dating Committee of the National Bureau of Economic Research, the recent recession period started from December 2007, and the recent expansion period started from June 2009. Therefore, in this paper, the recent recession period is defined as fourth quarter 2007 to second quarter 2009, and the expansion period is defined as third quarter 2009 to third quarter 2013.
} 
The impact of trading revenue and loan loss provision also shows very clear pro-cyclicality. Trading revenues of C, JPM and BAC which hold a significant share of assets in trading assets reduced the Basel III leverage ratio and the Tier 1 capital ratio during the recession. However, they increased these ratios in the recent expansion period. Loan loss provisions of C, JPM, BAC and WFC which hold a significant share of assets in net loans had a much greater negative impact on the Basel III leverage ratio and the Tier 1 capital ratio per quarter during the recession period than during the recent expansion period. And for these banks which hold a significant share of assets in net loans, loan loss provision in general had a much greater impact than that of fair value. However, the impact of fair value gains of JPM is greater than that of loan loss provision during the recent expansion period.

If all these pro-cyclical impacts are aggregated, both the Basel III leverage ratio and the Tier 1 capital ratio for all G-SIBs will be significantly reduced during the recession period. For the Basel III leverage ratio, the range of decrease is from 2.5 to 5.46 percentage points, and for the Basel III Tier 1 capital ratio, the range of decrease is from 3.74 to 11.47 percentage points. Therefore, the new capital requirements set by BCBS (2011) and BCBS (2013a) for G-SIBs may not be enough to mitigate the capital risk for all U.S. G-SIBs ${ }^{6}$.

\subsection{Interest rate sensitivity of Basel III regulatory capital ratios and bank capital risk}

The strong negative sensitivity of Basel III leverage ratio and Tier 1 capital ratio to interest rates may imply high bank capital risk in a changing interest rate environment. The decline of interest rates in general since 2007 may have improved Basel III regulatory capital ratios computed in this paper. However, as the U.S. economy is recovering, its monetary policy has begun tapering quantitative easing. This suggests that long-term interest rates may increase first and then short-term interest rates will normalize gradually afterwards. Such changes in the interest rate environment may reduce Basel III regulatory capital ratios for these G-SIBs.

\footnotetext{
${ }^{6}$ BCBS (2011) introduces $3 \%$ minimum leverage ratio, $6 \%$ minimum Tier 1 capital, $2.5 \%$ conservation buffer, and $0-2.5 \%$ countercyclical buffer. Moreover, BCBS (2013a) introduces additional loss absorbency requirements for G-SIBs, i.e. $1 \%$ to $2.5 \%$ CET1 capital.
} 
One risk generated by Basel III regulatory capital may come from unrealized gains or losses on AFS securities. For example, in May and June 2013 when U.S. FED Chairman Ben S. Bernanke first discussed the criteria for tapering, the 10-year Treasury yield increased from $1.99 \%$ for the first quarter 2013 to $2.71 \%$ for the second quarter, and it stays around this level in the third quarter 2013. It may be because of this increase of 0.72 percentage points in the long term interest rate, that unrealized losses on AFS securities decreased the Basel III leverage ratio and the Tier 1 capital ratio of all GSIBs in the second quarter of 2013 (see Panel C of Table 5).

If the 10-year Treasury yield returns to the level of $4.85 \%$ in the first quarter of 2007 before the recent recession, then these G-SIBs may suffer significant losses in Basel III regulatory capital ratios, especially for STT and BK. To illustrate, assume that the impact of unrealized losses on AFS securities generated by the increase of the long-term interest rate remains constant during the tapering period, the increase of 2.14 percentage points in 10 -year Treasury yield, i.e. from $2.71 \%$ to $4.85 \%$, may indicate that Basel III leverage ratio will decrease by 1.34 percentage points for STT and 0.87 percentage points for BK, and Basel III Tier 1 capital ratio will decrease by 3.67 percentage points for STT and 2.36 percentage points for BK. However, such impacts may still underestimate the capital risks generated by the long term interest rate as banks will hold more HQLA to meet Basel III LCR requirement.

In addition, as Basel III capital ratios have a similar negative correlation with the short-term interest rate, the normalization of the short term interest rate after tapering may further increase bank capital risk. This risk may be much greater as the short-term rate has to increase by 4.94 percentage points from $0.04 \%$ in the third quarter 2013 to reach $4.98 \%$ which was the level in the first quarter 2007 before this crisis.

\section{Conclusions}

This paper examines the pro-cyclical impact of Basel III regulatory capital on regulatory capital ratios and its consequent implications for bank capital risk for U.S. G-SIBs. As Basel III Tier 1 capital 
recognizes unrealized gains or losses on AFS securities, the pro-cyclical impact of fair value accounting on Basel III leverage ratio and Tier 1 capital ratio increases relative to that before Basel III. As unrealized gains or losses on AFS securities are sensitive to the long-term interest rate, Basel III capital standards also are more sensitive to the long-term interest rate.

The magnitude of the impact of Basel III capital standards depends on the asset structure of each bank. For banks which hold a significant share of AFS securities, the impact of unrealized losses on AFS securities on Basel III capital ratios in the recent recession could be significant. And the countercyclical buffer of $2.5 \%$ plus the additional loss absorbency requirements of $2.5 \%$ for G-SIBs may not be enough to mitigate the capital risk for G-SIBs which could be generated by the business cycle. The normalization of the long-term interest rate during the tapering period may generate another significant capital risk because the impact of AFS securities also has a strong negative sensitivity to long term interest rate. Moreover, banks may have to hold more HQLA and apply an EL approach for loan loss provisioning soon, so the capital risk may increase further. 


\section{References:}

Badertscher, B. A., Burks J. J. \& Easton P. D. (2012). A Convenient Scapegoat: Fair Value Accounting by Commercial Banks during the Financial Crisis. The Accounting Review, 87 (1), 59-90.

Ball, R., Jayaraman, S., \& Shivakumar, L. (2012). Mark-to-market Accounting and Information Asymmetry in Banks. Working paper, University of Chicago Booth School of Business.

BCBS (BASEL COMMITTEE ON BANKING SUPERVISION). (2011). Basel III: A Global Regulatory Framework for More Resilient Banks and Banking Systems - Revised Version, June. BCBS. (2013a). Global systemically important banks: updated assessment methodology and the higher loss absorbency requirement, July.

BCBS. (2013b). Basel III: The Liquidity Coverage Ratio and liquidity risk monitoring tools. January.

Dong, M., Ryan, S. G. \& Zhang, X. (2013). Preserving amortized costs within a fair-valueaccounting framework: reclassification of gains and losses on available-for-sale securities upon realization. Review of Accounting Studies, 28 August (online).

ECB (European Central Bank). (2004). Fair Value Accounting and Financial Stability. European Central Bank Occasional Paper, No. 13.

ECB. (2009). Is Basel II Pro-cyclical? A Selected Review of the Literature. Financial Stability Review, December,143-150.

FSA. (2009). The Turner Review: A Regulatory Response to the Global Banking Crisis, March.

FSB (Financial Stability Board). (2011). Policy Measures to Address Systemically Important Financial Institutions, 4 November. 
Greenspan, A. (1990). Letter to Hon. Richard C. Breeden, Federal Reserve, 1 November 11990.

IASB (International Accounting Standards Board). (2013a). IASB Update, November.

IASB. (2013b). Exposure Draft ED/2013/3 Financial Instruments: Expected Credit Losses.

IMF (International Monetary Fund). (2008). Chapter 3: Fair Value Accounting and Procyclicality, Global Financial Stability Report, October 2008.

ISDA. (2012). Letter to Mr Stefan Ingves, Chairman Basel Committee and Mr Hans Hoogervorst, Chairman International Accounting Standards Board, 29 June.

Laux, C. \& Leuz C. (2010). Did Fair-Value Accounting Contribute to the Financial Crisis? Journal of Economic Perspectives, 24, 93-118.

Saunders, A \& Cornett M. (2011). Financial Institutions Management: A Risk Management Approach, Seventh Edition. New York: McGraw-Hill.

SEC. (2008). Report and Recommendations Pursuant to Section 133 of the Emergency Economic Stabilization Act of 2008: Study on Mark-To-Market Accounting.

Shaffer, S. (2010). Fair Value Accounting: Villain or Innocent Victim - Exploring the Links Between Fair Value Accounting, Bank Regulatory Capital and the Recent Financial Crisis, FRB of Boston Quantitative Analysis Unit Working Paper, No. 10-01.

Sill, K., (1996). The Cyclical Volatility of Interest Rates. Business Review: January-February, 1529.

Song, G., (2012). Can accounting rules be made neutral for bank capital regulation? Journal of Governance and Regulation, 1 (3), 27-35. 
Tarullo, D. K. (2011). The Evolution of Capital Regulation, Speech at the Clearing House Business Meeting and Conference. New York, November 9.

The Agencies (Department of the Treasury and Federal Reserve System). (2013). Regulatory Capital Rules. Federal Register, 78 (198): 62018-62291. 
Table 1 Assets at fair value on a recurring basis and net loans relative to total assets (\%)

\begin{tabular}{|c|c|c|c|c|c|c|c|c|}
\hline & \multicolumn{6}{|c|}{ Assets at fair value } & \multicolumn{2}{|c|}{ Net loans } \\
\hline & \multicolumn{3}{|c|}{$30 / 06 / 2007$} & \multicolumn{3}{|c|}{$30 / 09 / 2013$} & $30 / 06 / 2007$ & $30 / 09 / 2013$ \\
\hline & $\begin{array}{c}\text { Total of } \\
\text { fair value }\end{array}$ & $\begin{array}{l}\text { Trading } \\
\text { assets }\end{array}$ & $\begin{array}{c}\text { AFS } \\
\text { securities }\end{array}$ & $\begin{array}{l}\text { Total of fair } \\
\text { value }\end{array}$ & $\begin{array}{l}\text { Trading } \\
\text { assets }\end{array}$ & $\begin{array}{c}\text { AFS } \\
\text { securities }\end{array}$ & & \\
\hline STT & 60.4 & 0.76 & 55.89 & 48.59 & 2.21 & 46.22 & 10.73 & 7.18 \\
\hline $\mathrm{C}$ & 42.23 & 24.24 & 11.11 & 40.46 & 15.36 & 14.73 & 32.98 & 33.53 \\
\hline JPM & 40.68 & 30.9 & 6.58 & 32.26 & 15.56 & 14.25 & 31.37 & 28.87 \\
\hline BAC & 27.63 & 13.83 & 11.23 & 31.25 & 13.16 & 11.16 & 48.85 & 42.98 \\
\hline BK & 24.18 & 2.67 & 20.41 & 27.55 & 3.29 & 20.73 & 30.18 & 13.42 \\
\hline WFC & 23.91 & 1.35 & 13.37 & 24.69 & 4.05 & 17.46 & 62.79 & 53.57 \\
\hline Aggregate & 36.42 & 20.24 & 11.28 & 32.72 & 12.05 & 15.24 & 38.86 & 36.48 \\
\hline
\end{tabular}

Notes:

Aggregate is estimated using the sum of assets of all 6 banks

Estimated using data from Form 10-Q and FRY 9-C

AFS: available - for - sale security

C: Citigroup; BAC: Bank of America; JPM: JPMorgan Chase; WFC: Wells Fargo \& Company; BK: The Bank of New York Mellon; STT: State Street Corporation 
Table 2 Correlations between leverage ratios, Tier 1 capital ratios in quarter $t$ and real GDP growth rates in quarter $t-1, t$ and $t+1$ (2007:Q1 - 2013: Q3)

Panel A Leverage ratio

\begin{tabular}{|lcccccc|}
\hline & \multicolumn{2}{c}{ GDP (t-1) } & \multicolumn{2}{c}{ GDP(t) } & \multicolumn{2}{c|}{ GDP(t+1) } \\
& Basel & Before & Basel & Before & Basel & Before \\
& III & Basel III & III & Basel III & III & Basel III \\
STT & 0.27 & -0.26 & 0.38 & -0.18 & 0.27 & -0.1 \\
C & 0.11 & 0.02 & 0.36 & 0.27 & 0.46 & 0.4 \\
JPM & -0.02 & -0.07 & -0.06 & -0.17 & 0.19 & 0.06 \\
BAC & 0.11 & 0.06 & 0.41 & 0.37 & 0.45 & 0.38 \\
BK & 0.21 & -0.48 & 0.07 & -0.36 & 0.23 & -0.19 \\
WFC & -0.28 & -0.37 & 0.02 & -0.13 & 0.23 & 0.06 \\
\hline
\end{tabular}

Panel B Tier 1 capital ratio

\begin{tabular}{|lcccccc|}
\hline & \multicolumn{2}{c}{ GDP (t-1) } & \multicolumn{2}{c}{ GDP(t) } & \multicolumn{2}{c|}{ GDP(t+1) } \\
& Basel & Before & Basel & Before & Basel & Before \\
& III & Basel III & III & Basel III & III & Basel III \\
STT & 0.31 & -0.18 & 0.38 & -0.11 & 0.35 & 0.05 \\
C & 0.09 & 0 & 0.33 & 0.25 & 0.44 & 0.39 \\
JPM & 0.1 & 0.08 & 0.27 & 0.24 & 0.41 & 0.37 \\
BAC & 0.2 & 0.17 & 0.4 & 0.38 & 0.45 & 0.41 \\
BK & 0.27 & -0.04 & 0.25 & 0.15 & 0.41 & 0.34 \\
WFC & 0.36 & 0.36 & 0.51 & 0.46 & 0.55 & 0.47 \\
\hline
\end{tabular}

Panel C Basel III Leverage ratio

\begin{tabular}{|lcccccc|}
\hline & STT & C & JPM & BAC & BK & WFC \\
STT & 1 & & & & & \\
C & 0.77 & 1 & & & & \\
JPM & 0.58 & 0.76 & 1 & & & \\
BAC & 0.69 & 0.83 & 0.46 & 1 & & \\
BK & 0.46 & 0.31 & 0.19 & 0.43 & 1 & \\
WFC & 0.19 & 0.57 & 0.53 & 0.45 & 0.14 & 1 \\
\hline
\end{tabular}

Notes:

Estimated using models in this paper

Data sources: 10-Q and FRY 9-C, U.S. Bureau of Economic Analysis

C: Citigroup; BAC: Bank of America; JPM: JPMorgan Chase; WFC: Wells Fargo \& Company; BK: The Bank of New York Mellon; STT: State Street Corporation 
Table 3 Correlations between the impacts of fair value and loan loss provision on Basel III leverage ratio in quarter $t$ and real GDP growth rates in quarter $t-1, t$ and $t+1(2007: Q 1$ - 2013: $Q 3)$

Panel A Impact of fair value and loan loss provision on Basel III leverage ratio

\begin{tabular}{|lcccccc|}
\hline & \multicolumn{2}{c}{$\mathrm{GDP}(\mathrm{t}-1)$} & \multicolumn{2}{c}{$\mathrm{GDP}(\mathrm{t})$} & \multicolumn{2}{c|}{$\mathrm{GDP}(\mathrm{t}+1)$} \\
& Fair & Loan loss & Fair & Loan loss & Fair & Loan loss \\
& value & provision & value & provision & value & provision \\
$\mathrm{STT}$ & 0.3 & 0.72 & 0.67 & 0.35 & 0.39 & 0.13 \\
$\mathrm{C}$ & 0.11 & 0.62 & 0.48 & 0.64 & 0.63 & 0.5 \\
JPM & 0.08 & 0.46 & 0.47 & 0.62 & 0.63 & 0.58 \\
BAC & -0.03 & 0.72 & 0.21 & 0.64 & 0.57 & 0.43 \\
BK & 0.52 & 0.61 & 0.78 & 0.3 & 0.44 & 0.25 \\
WFC & 0.18 & 0.48 & 0.39 & 0.76 & 0.57 & 0.59 \\
\hline
\end{tabular}

Panel B Correlations between impact of fair value on Basel III leverage ratio in quarter $\mathrm{t}$

\begin{tabular}{|lcccccc|}
\hline & STT & C & JPM & BAC & BK & WFC \\
STT & 1 & & & & & \\
C & 0.27 & 1 & & & & \\
JPM & 0.4 & 0.7 & 1 & & & \\
BAC & 0.32 & 0.3 & 0.68 & 1 & & \\
BK & 0.85 & 0.28 & 0.48 & 0.3 & 1 & \\
WFC & 0.5 & 0.42 & 0.84 & 0.8 & 0.58 & 1 \\
\hline
\end{tabular}

Panel $\mathrm{C}$ Correlations between impact of fair value in quarter $\mathrm{t}$ and that of loan loss provision in quarter $\mathrm{t}-1$, $\mathrm{t}$ and $\mathrm{t}+1$ on Basel III leverage ratio for each bank

\begin{tabular}{|lcccccc|}
\hline & STT & C & JPM & BAC & BK & WFC \\
Loan loss provision $(t-1)$ & -0.22 & 0.14 & 0.23 & -0.15 & 0.29 & 0.29 \\
Loan loss provision(t) & 0.46 & 0.48 & 0.40 & 0.00 & 0.31 & 0.47 \\
Loan loss provision $(t+1)$ & 0.29 & 0.43 & 0.44 & 0.21 & 0.53 & 0.42 \\
\hline
\end{tabular}

Panel D Impact on Basel III leverage ratio of unrealized gains and losses on AFS in quarter t

\begin{tabular}{lcccccc|}
\hline & STT & $C$ & JPM & BAC & BK & WFC \\
GDP $(t-1)$ & 0.29 & 0.32 & 0.08 & 0.2 & 0.29 & 0.24 \\
GDP $(t)$ & 0.67 & 0.52 & 0.15 & 0.06 & 0.49 & 0.39 \\
GDP $(t+1)$ & 0.4 & 0.41 & 0.32 & 0.21 & 0.44 & 0.54 \\
\hline
\end{tabular}

Notes:

Estimated using models in this paper

Data sources: 10-Q and FRY 9-C, U.S. Bureau of Economic Analysis

C: Citigroup; BAC: Bank of America; JPM: JPMorgan Chase; WFC: Wells Fargo \& Company; BK: The Bank of New York Mellon; STT: State Street Corporation 
Table 4 Correlations between leverage ratios, Tier 1 capital ratios and interest rates (2007:Q1 - 2013: Q3)

Panel A Leverage ratio

\begin{tabular}{|lcccc|}
\hline & \multicolumn{2}{c}{10 Year Treasury Note } & \multicolumn{2}{c|}{3 Month Treasury Bill } \\
& Basel III & Before Basel III & Basel III & Before Basel III \\
STT & -0.47 & -0.43 & -0.55 & -0.69 \\
C & -0.69 & -0.71 & -0.62 & -0.67 \\
JPM & -0.73 & -0.67 & -0.7 & -0.68 \\
BAC & -0.45 & -0.48 & -0.46 & -0.47 \\
BK & 0.01 & 0.66 & -0.02 & 0.31 \\
WFC & -0.43 & -0.36 & -0.41 & -0.36 \\
\hline
\end{tabular}

Panel B Tier 1 capital ratio

\begin{tabular}{|lcccc|} 
& \multicolumn{2}{c}{10 Year Treasury Note } & \multicolumn{2}{c|}{3 Month Treasury Bill } \\
STT & Basel III & Before Basel III & Basel III & Before Basel III \\
C & -0.72 & -0.75 & -0.57 & -0.73 \\
JPM & -0.74 & -0.75 & -0.66 & -0.7 \\
BAC & -0.77 & -0.76 & -0.7 & -0.71 \\
BK & -0.69 & -0.71 & -0.56 & -0.56 \\
WFC & -0.62 & -0.84 & -0.5 & -0.75 \\
\hline
\end{tabular}

Panel C The impact of fair value and loan loss provision on Basel III Leverage ratio

\begin{tabular}{|lcccc|}
\hline & \multicolumn{2}{c}{10 Year Treasury Note } & \multicolumn{2}{c|}{3 Month Treasury Bill } \\
& Fair value & Loan loss provision & Fair value & Loan loss provision \\
STT & -0.08 & -0.18 & 0.06 & 0.19 \\
C & -0.23 & -0.31 & -0.06 & 0.18 \\
JPM & -0.09 & -0.31 & 0.05 & 0.16 \\
BAC & -0.1 & -0.32 & -0.19 & 0.22 \\
BK & -0.15 & -0.49 & 0.05 & -0.13 \\
WFC & -0.13 & -0.2 & -0.1 & 0.12 \\
\hline
\end{tabular}

Panel D The impact of unrealized gains and losses on AFS on Basel III Leverage ratio

\begin{tabular}{|lcccccc|}
\hline & STT & C & JPM & BAC & BK & WFC \\
10 Year Treasury Note & -0.06 & -0.11 & -0.28 & -0.16 & -0.17 & 0.02 \\
3 Month Treasury Bill & -0.08 & 0 & -0.39 & -0.21 & 0.06 & 0.15 \\
\hline
\end{tabular}

Notes:

Estimated using models in this paper

Data sources: 10-Q and FRY 9-C, U.S. Federal Reserve Bank of St. Louis

C: Citigroup; BAC: Bank of America; JPM: JPMorgan Chase; WFC: Wells Fargo \& Company; BK: The Bank of New York Mellon; STT: State Street Corporation 


\section{Table 5 The pro-cyclical impact of Basel III regulatory capital}

Panel A The accumulated pro-cyclical impact of fair value gains and losses and loan loss provision on Basel III leverage ratio

Accumulated percentage change of starting Basel III leverage ratio

\begin{tabular}{|c|c|c|c|c|c|c|c|c|c|c|c|c|}
\hline & \multicolumn{6}{|c|}{ Fourth Quarter 2007 to Second Quarter 2009} & \multicolumn{6}{|c|}{ Third Quarter 2009 to Third Quarter 2013} \\
\hline & STT & $\mathrm{C}$ & JPM & BAC & BK & WFC & STT & $\mathrm{C}$ & JPM & BAC & BK & WFC \\
\hline Trading revenue & 1.12 & -1.66 & -0.31 & -0.30 & 2.54 & 0.23 & 1.45 & 1.25 & 2.06 & 1.31 & 1.32 & 0.50 \\
\hline Loan loss provision & -0.05 & -2.91 & -2.23 & -2.85 & -0.18 & -3.96 & -0.05 & -3.48 & -2.01 & -3.03 & -0.06 & -3.35 \\
\hline AFS: unrealized gains and losses & -5.78 & -0.78 & -0.11 & 0.38 & -4.22 & -1.21 & 0.49 & -0.03 & 0.83 & 0.80 & 2.56 & 1.78 \\
\hline AFS: realized gains and losses & 0.03 & 0.12 & -0.15 & -0.16 & 2.01 & 0.01 & -0.13 & -0.37 & -0.35 & -0.71 & 1.88 & -0.04 \\
\hline Total fair value gains and losses & -4.69 & -2.55 & -0.28 & 0.24 & -3.70 & -0.99 & 2.08 & 1.59 & 3.25 & 2.82 & 2.00 & 2.31 \\
\hline Sum of fair value and loan loss provision & -4.74 & -5.46 & -2.50 & -2.61 & -3.88 & -4.95 & 2.04 & -1.88 & 1.24 & -0.21 & 1.94 & -1.03 \\
\hline
\end{tabular}

Panel B The accumulated pro-cyclical impact of fair value gains and losses and loan loss provision on Basel III Tier 1 capital ratio Accumulated percentage change of starting Basel III Tier 1 capital ratio

\begin{tabular}{|c|c|c|c|c|c|c|c|c|c|c|c|c|}
\hline & \multicolumn{6}{|c|}{ Fourth Quarter 2007 to Second Quarter 2009} & \multicolumn{6}{|c|}{ Third Quarter 2009 to Third Quarter 2013} \\
\hline & STT & $\mathrm{C}$ & JPM & BAC & BK & WFC & STT & $\mathrm{C}$ & JPM & BAC & BK & WFC \\
\hline Trading revenue & 2.44 & -2.94 & -0.34 & -0.40 & 3.75 & 0.21 & 3.48 & 2.42 & 3.69 & 2.22 & 3.14 & 0.65 \\
\hline Loan loss provision & -0.14 & -5.53 & -3.45 & -4.22 & -0.30 & -4.47 & -0.10 & -6.93 & -3.56 & -5.14 & -0.05 & -4.43 \\
\hline AFS: unrealized gains and losses & -13.70 & -1.51 & -0.16 & 0.53 & -7.26 & -1.19 & 0.88 & -0.01 & 1.52 & 1.35 & 5.41 & 2.31 \\
\hline AFS: realized gains and losses & 0.07 & 0.14 & -0.22 & -0.25 & 3.02 & -0.02 & -0.33 & -0.74 & -0.64 & -1.21 & 3.11 & -0.05 \\
\hline Total fair value gains and losses & -11.33 & -4.59 & -0.28 & 0.38 & -6.52 & -0.96 & 4.69 & 3.14 & 5.85 & 4.78 & 5.44 & 3.02 \\
\hline Sum of fair value and loan loss provision & -11.47 & -10.12 & -3.74 & -3.84 & -6.82 & -5.43 & 4.59 & -3.79 & 2.28 & -0.35 & 5.39 & -1.41 \\
\hline
\end{tabular}


Panel C The impact of unrealized and realized gains and losses on AFS on Basel III leverage ratio and Tier 1 capital ratio (First Quarter 2013 to Third Quarter 2013)

\begin{tabular}{|c|c|c|c|c|c|c|c|c|c|c|c|c|}
\hline & \multicolumn{2}{|c|}{ STT } & \multicolumn{2}{|c|}{$\mathrm{C}$} & \multicolumn{2}{|c|}{ JPM } & \multicolumn{2}{|c|}{ BAC } & \multicolumn{2}{|c|}{ BK } & \multicolumn{2}{|c|}{ WFC } \\
\hline & Unrealized & Realized & Unrealized & Realized & Unrealized & Realized & Unrealized & Realized & Unrealized & Realized & Unrealized & Realized \\
\hline \multicolumn{13}{|c|}{ Impact on leverage ratio (Percentage point) } \\
\hline 2013Q1 & 0.25 & 0.00 & 0.04 & 0.02 & 0.26 & 0.02 & 0.18 & 0.00 & 0.39 & 0.01 & 0.47 & 0.01 \\
\hline 2013Q2 & -0.35 & 0.00 & -0.10 & 0.01 & -0.13 & 0.01 & -0.18 & 0.02 & -0.23 & 0.01 & -0.25 & 0.00 \\
\hline 2013Q3 & 0.05 & 0.00 & 0.00 & 0.00 & 0.01 & 0.00 & -0.03 & 0.05 & -0.02 & 0.01 & 0.02 & 0.01 \\
\hline \multicolumn{13}{|c|}{ Impact on Tier 1 capital ratio (Percentage point) } \\
\hline 2013Q1 & 0.71 & 0.01 & 0.08 & 0.03 & 0.48 & 0.04 & 0.33 & 0.00 & 1.16 & 0.04 & 0.64 & 0.01 \\
\hline 2013Q2 & -0.96 & -0.01 & -0.19 & 0.02 & -0.22 & 0.01 & -0.32 & 0.03 & -0.62 & 0.03 & -0.34 & 0.00 \\
\hline 2013Q3 & 0.14 & 0.01 & -0.01 & 0.01 & 0.01 & 0.00 & -0.05 & 0.09 & -0.06 & 0.02 & 0.03 & 0.01 \\
\hline
\end{tabular}

Notes:

Estimated using models in this paper

Data sources: 10-Q and FRY 9-C

C: Citigroup; BAC: Bank of America; JPM: JPMorgan Chase; WFC: Wells Fargo \& Company; BK: The Bank of New York Mellon; STT: State Street Corporation

U.S. Interest rate data is from U.S. Federal Reserve Bank of St. Louis 
